\title{
Atrakcyjność wizualna krajobrazu doliny Mrogi i jej sąsiedztwa w gminie Dmosin
}

\section{Visual attractiveness of landscape of the Mroga valley and its surroundings in Dmosin commune}

\begin{abstract}
Zarys treści: Głównym celem artykułu była ocena atrakcyjności wizualnej krajobrazu fragmentu doliny Mrogi wraz z jej najbliższym sąsiedztwem w granicach administracyjnych gminy Dmosin. Oceny tej dokonano przy zastosowaniu metody fotograficznej Cymermana i Hopfera (1988), zmodyfikowanej przez Hajnrych (2006). Metoda polegała na ocenie 426 fotografii wykonanych z 72 stanowisk dokumentacyjnych, zlokalizowanych wzdłuż doliny rzeki Mrogi. Na podstawie wyników oceny wydzielono pięć klas atrakcyjności wizualnej krajobrazu. Największy udział mają tereny o niewielkiej i przeciętnej atrakcyjności wizualnej, a obszarów o dużej i bardzo dużej atrakcyjności jest niewiele. Do artykułu dołączono opracowaną na podstawie badań mapę atrakcyjności wizualnej krajobrazu.
\end{abstract}

Słowa kluczowe: krajobraz, atrakcyjność wizualna, dolina Mrogi, region łódzki.

Abstract:

The main aim of this paper was an evaluation of the visual attractiveness of landscape of the Mroga valley and its surroundings in the administrative borders of the Dmosin commune. That evaluation was made by a photographic method of Cymerman and Hopfer (1988), modified by Hajnrych (2006). The method was based on an evaluation of 426 photographs taken at the 72 documentation sites located along the valley of Mroga river valley. On the basis of results of the assessment, it established five classes of visual attractiveness of the landscape were established, of which the largest share included areas of low and average visual attractiveness. Areas of high and very high visual attractiveness were few. A map of visual attractiveness of the landscape was made.

Key words: $\quad$ landscape, visual attractiveness, Mroga valley, region of tódź.

\section{Wstęp}

Wraz z rozwojem cywilizacyjnym rośnie skala antropogenicznych oddziaływań na środowisko przyrodnicze. Ich konsekwencją są przemiany krajobrazów, które najczęściej wyrażają się w spadku naturalności i postępującym udziale różnorodnych form krajobrazu kulturowego. Wspomniane przemiany wpływają na potencjał krajobrazu, którego jednym z aspektów są szeroko rozumiane walory turystyczne.

Walory przyrodnicze odgrywają niezwykle ważną rolę wocenieśrodowiska podkątem potrzeb turystykiiwypoczynku, przede wszystkim jeżeli chodzi o jego aspekt wizualny, któryjest bardzo ważną cechą krajobrazu (Kowalczyk 1992). Badania wykazały, że turyści, decydująco wyborze miejsca na wypoczynek, w pierwszej kolejności wybierają te, które charakteryzują się atrakcyjnymi widokami - ciekawymi krajobrazami i innymi walorami przyrodniczymi. Znacznie rzadziej biorą pod uwagę elementy zagospodarowania turystycznego (Pizam, Neumann, Reichel 1978).

Badania nad estetyką krajobrazu w ciągu ostatnich lat stały się jednymi z częściej podejmowanych przez geografów krajobrazu tematów. Zostały zapoczątkowane w latach 60. XX wieku w Stanach Zjednoczonych, kiedy zauważono, że obszary leśne powinny być traktowane nie tylko jako źródło drewna, ale także jako tereny o niezwykle cennych walorach przyrodniczych i estetycznych. Obecnie badania nad estetyką krajobrazu wykorzystywane są w różnych celach - najczęściej przy wyznaczaniu obszarów turystycznych lub terenów przeznaczonych do ochrony. Obszary wizualnie atrakcyjne mogą również wpływać na podniesienie wartości nieruchomości (Richling 1992).
Badania nad atrakcyjnością wizualną były prowadzone przez licznych badaczy. W Polsce tą tematyką zajmowali się m.in. Wojciechowski (1986) czy Śleszyński (1999), który zaproponował kompleksową metodę oceny atrakcyjności, stosując ją przy waloryzacji okolic Pińczowa. W ocenie walorów estetycznych tras wiodących przez otwarte krajobrazy wiejskie interesującym rozwiązaniem metodycznym jest krzywa wrażeń Wejcherta, którą do warunków polskich zaadaptowali Cymerman, Hopfer, Koreleski, Magiera-Braś (1988). W opisywanym nurcie badawczym szczególne znaczenie posiadają zdjęcia fotograficzne. Metody z zastosowaniem fotografii wykorzystywane były m.in. przez Skarżyńskiego (1992), który oceniał walory estetyczne widoków okolic Piecek na Pojezierzu Mazurskim; Pietrzaka, Miedzińską, Styperka (1999), którzy badali rzeczywistą atrakcyjność wizualną krajobrazu szlaku turystycznego im. C. Ratajskiego w Wielkopolskim Parku Narodowym; Chmielewskiego i in. $(2014,2015)$ w metrykach jednostek przyrodniczo-krajobrazowych Roztocza oraz ukazaniu specyfiki krajobrazu przyrodniczego i kulturowego Polesia Zachodniego. Szczególne znaczenie spełniają fotografie w identyfikacji krajobrazów metodą zaproponowaną przez ECOVAST (European Council for the Village and Small Town) w instrukcji ECOVAST Landscape Identification. A guide to good practice (2006) (www.ecovast.org). Metoda ta na gruncie polskim została zastosowana m.in. w metrykach krajobrazów wiejskich Polski środkowej, czego przykładem są opracowania Lidke (2014) dla gminy Inowłódz, Królewskiego (2014) dla gminy Ręczno oraz zaprezentowana w formie posteru przez Królewskiego, Lidke i Majchrowską (2015). 
Jednym z istotnych problemów w badaniach estetyki krajobrazu jest dobór odpowiedniej metody badawczej. Trzeba zauważyć, że nie ma uniwersalnej metody oceny walorów estetycznych krajobrazu. Badać walory estetyczne krajobrazu można na różne sposoby, przy czym jedną z ciekawszych metod jest wykorzystywanie w tym celu zdjęć fotograficznych (Kowalczyk 1992). Fotografie są bowiem bardzo przydatne do odczytywania zmian zachodzących w krajobrazie, stanowią również cenną dokumentację aktualnego stanu badanego obszaru.

\section{Obszar badań}

Zuwaginaspecyfikęprowadzonychbadańniezwykleważnym wydaje się być scharakteryzowanie analizowanego obszaru pod względem cech środowiska przyrodniczego. Opisywany teren doliny Mrogi i jej sąsiedztwa posiada bowiem bardzo malownicze położenie oraz niezwykłe walory krajobrazowe. Budowa geologiczna, rzeźba obszaru, a także procesy, które go kształtowały miały znaczny wpływ na obecną jego formę i krajobraz, jaki utworzył się na tym terenie. Duży wpływ na wygląd krajobrazu wywarły również zmiany wywołane działalnością człowieka.

Badany teren zajmuje powierzchnię około $44 \mathrm{~km}^{2}$. Zlokalizowany jest w województwie łódzkim, w powiecie brzezińskim oraz w niewielkiej części powiatu zgierskiego, w granicach gminy Dmosin, a częściowo także gminy Rogów i gminy Głowno. Obejmuje on obszar środkowej części doliny rzeki Mrogi wraz z fragmentami przyległych wysoczyzn. Rzeka Mroga, stanowiąca oś hydrograficzną obszaru, przepływa przez centralną część gminy Dmosin w kierunku z południowego wschodu na północny zachód. W granicach gminy szerokość koryta rzecznego Mrogi waha się od 0,5 do $3 \mathrm{~m}$. Jest ono nieuregulowane, posiada liczne meandry oraz starorzecza (Prognoza... 2009).

Znaczny wpływ na rozwój krajobrazów doliny Mrogi miała rzeźba tego terenu. Zlokalizowany na obszarze staroglacjalnym zlodowacenia środkowopolskiego $w$ strefie równinnej powierzchni wysoczyzny morenowej teren, wyraźnie obniża się w kierunku północno-zachodnim. Wysokości względne wahają się od 131,25 m n.p.m. w północnej części obszaru do 195 m n.p.m. w części południowej (rys. 1). Dominuje tu rzeźba erozyjno-denudacyjna (Turkowska 2006).

Dolina rzeki Mrogi jest jedną z najbardziej urozmaiconych dolin województwa łódzkiego (Turkowska 1988). Charakteryzuje się ostrymi krawędziami oraz towarzyszącymi jej licznymi, często suchymi, głęboko wciętymi dolinkami bocznymi. Jej najbardziej reprezentatywną cechą jest asymetria stoków. Lewobrzeżne stoki są dłuższe i łagodniejsze niż prawobrzeżne. Stoki po prawej stronie doliny są strome i często mają charakter podcięć erozyjnych. Dolne części stoków po stronie wschodniej różnią się od stoków po stronie zachodniej. Nawiązują do wyższego poziomu dolinnego, ograniczonego krawędzią doliny holoceńskiej. $\mathrm{Na}$ stokach zachodnich natomiast poziom ten zaznacza się spłaszczeniem, odpowiadającym terasie niskiej, które łączy się z holoceńskim dnem doliny Mrogi (Kuydowicz-Turkowska 1975).

Jeśli chodzi o warunki klimatyczne obszaru badań, można je określić jako relatywnie korzystne, biorąc pod uwagę potrzeby gospodarcze. Obszar charakteryzuje się stosunkowo małym zachmurzeniem, dużą ilością dni pogodnych, wysokimi sumami promieniowania słonecznego i znaczną liczbą godzin ze słońcem. Obszar jest jednym z najcieplejszych w Polsce. Na podkreślenie zasługują walory klimatyczne obszaru w zakresie rozwoju turystyki i rekreacji - przede wszystkim w ciepłej porze roku. Znaczna liczba dni pogodnych oraz długotrwały okres ciepły są głównymi pozytywnymi cechami bioklimatu obszaru badań (Misiewicz-Śnieszko 1982).

\section{Metody badań}

Do oceny atrakcyjności wizualnej krajobrazu zastosowano metodę zaproponowaną przez Cymermana i Hopfera (1988), zmodyfikowaną przez Hajnrych (2006). Metoda ta polega na ocenie krajobrazu na podstawie obrazu zarejestrowanego na zdjęciach fotograficznych.

Badania terenowe przeprowadzone latem 2014 roku przez Mirowską (2015), polegające na zrobieniu zdjęć z wyznaczonych stanowisk dokumentacyjnych, objęły obszar środkowego odcinka doliny rzeki Mrogi i jej najbliższego sąsiedztwa znajdującego się w granicach administracyjnych gminy Dmosin, a także w południowej części gminy Głowno oraz w północnej części gminy Rogów. Gmina Dmosin ma dość korzystne warunki glebowe i jest gminą ukierunkowaną na produkcję rolniczą. Zdecydowanie największą jej część stanowią zatem grunty orne, a także sady i plantacje.

Pierwszym etapem realizacji oceny atrakcyjności wizualnej krajobrazu na obszarze objętym badaniami był wybór stanowisk dokumentacyjnych, z których wykonywane były zdjęcia. Cymerman i Hopfer (1988) proponowali, aby stanowiskami dokumentacyjnymi były wierzchołki siatki kwadratów. Przy takim rozwiązaniu z każdego stanowiska wykonywali cztery zdjęcia (w kierunku północnym, wschodnim, południowym i zachodnim) aparatem z obiektywem szerokokątnym, o kącie widzenia nie mniejszym niż 900 . Każde zdjęcie obejmowało $1 / 4$ panoramy możliwej do zaobserwowania z danego stanowiska. Ponieważ pole widzenia oka ludzkiego jest mniejsze od $90^{\circ}$, przyjmując wielkość zbliżoną do $60^{\circ}$, w ocenie atrakcyjności doliny Mrogi wykorzystano modyfikację tej metody, zaproponowaną przez Hajnrych (2006), polegającą na zastąpieniu siatki pól podstawowych złożonej z kwadratów na pola o kształcie sześciokątów (plastrów miodu). Wówczas polami oceny nie są kwadraty, jak w oryginalnej wersji metody, lecz trójkąty równoboczne. Każde stanowisko dokumentacyjne ilustruje sześć fotografii wykonanych aparatem umieszczonym na statywie połączonym z busolą. W kolejnych zdjęciach oś optyczną obiektywu wyznaczały azymuty: $0^{\circ}, 60^{\circ}, 120^{\circ}, 180^{\circ}, 240^{\circ}, 300^{\circ}$ (rys. 2).

W procedurze badawczej przyjęto, że długość boku każdego z trójkątów będzie wynosiła $250 \mathrm{~m}$. Zakładano tym samym, że obszar widoczny na fotografii będzie obejmował plany i obiekty znajdujące się w granicach powyższej odległości od obserwatora. Przestrzenny układ pól podstawowych i lokalizację stanowisk dokumentacyjnych, przyjętych do oceny atrakcyjności wizualnej doliny Mrogi i jej sąsiedztwa przedstawiono na rys. 3.

Kolejny etap obejmował badania terenowe, w ramach których szczegółowo analizowano pokrycie terenu. Następnie dla 71 stanowisk dokumentacyjnych wykonano zestawy zdjęć, składające się z sześciu fotografii.

Po zakończeniu prac terenowych przystąpiono do oceny atrakcyjności wizualnej krajobrazu na wykonanych zdjęciach. Ocena dokonywana była na podstawie wybranych 


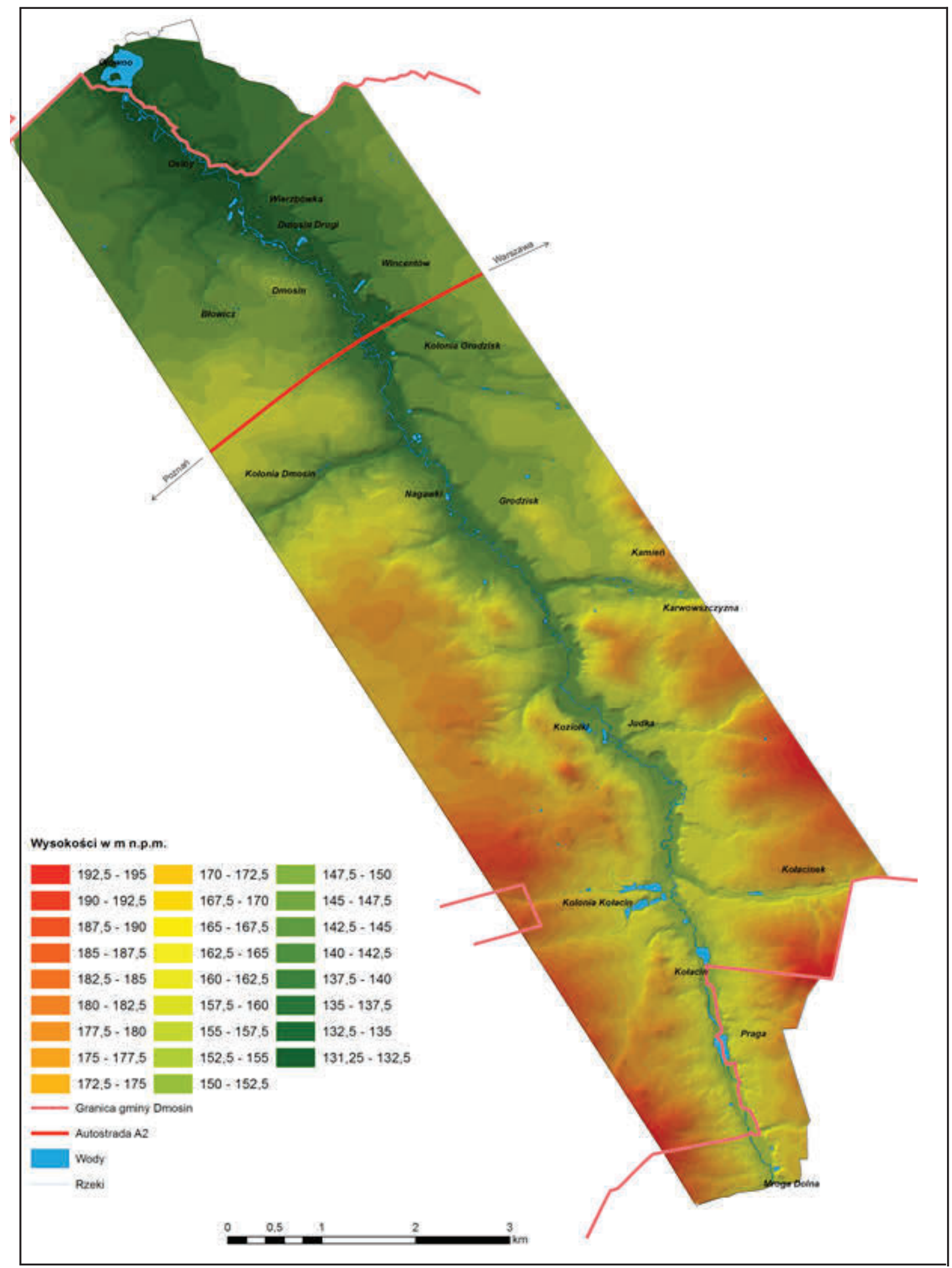

Rys. 1. Numeryczny model terenu wykonany dla badanego obszaru

Fig. 1. DEM made for the investigated area 


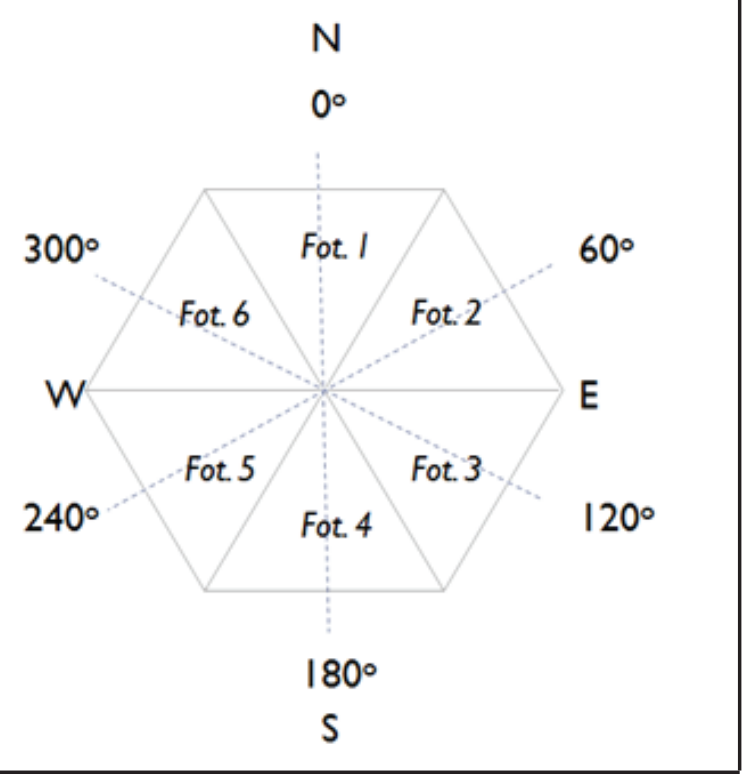

Rys. 2. Układ fotografii wykonywanych z jednego stanowiska dokumentacyjnego

Źródło: opracowanie własne, nawiązujące do modyfikacji metody fotograficznej wg Hajnrych (2006)

Fig. 2. Arrangement of photographs made from one research position Source: own compilation referring to modification of photographic method according to Hajnrych (2006)

kryteriów oceny, zaproponowanych przez Skarżyńskiego (1992) (tab. 1). Punkty, jakie uzyskały poszczególne zdjęcia (trójkąty), zostały przeniesione do siatki pól podstawowych, naniesionej na mapę ocenianego obszaru; zaznaczone zostały rejony o różnej wartości krajobrazowej. Przykładowe stanowisko badawcze z wykonanymi fotografiami oraz ich oceną przedstawia rys. 4.

Wynikiem oceny zdjęć jest mapa atrakcyjności wizualnej krajobrazu z ocenionymi polami podstawowymi.

Według wymienionych kryteriów najwyższą oceną, jaką dany obszar mógł uzyskać, były 24 punkty, najniższą zaś 1 punkt.

Analizowany obszar podzielono na pięć klas atrakcyjności wizualnej krajobrazu:

- poniżej 6 punktów - obszary nieatrakcyjne wizualnie;

- 7-11 punktów - obszary o niewielkiej atrakcyjności wizualnej;

-12-13 punktów - obszary o przeciętnej atrakcyjności wizualnej;

-14-16 punktów - obszary o dużej atrakcyjności wizualnej;

- powyżej 17 punktów - obszary o bardzo dużej atrakcyjności wizualnej.

\section{Wyniki badań}

W trakcie badań oceniono zdjęcia z wyznaczonych 72 stanowisk. Jedno z tych stanowisk nie zostało ocenione ze względu na to, że w wyznaczonym miejscu znajduje się ogrodzony teren prywatny należący do gospodarstwa agroturystycznego. W związku z tym ocenie podlegało 71 stanowisk, a co za tym idzie, część dokumentacyjną zmodyfikowanej metody fotograficznej stanowi 426 zdjęć. Wynik oceny przedstawia rys. 5 .

Po dokonaniu oceny każdego ze zdjęć okazało się, że najwyższą uzyskaną oceną było 20 punktów, najniższą zaś 5 punktów. Obszary, które otrzymały ocenę 6 punktów
Tab. 1. Kryteria oceny atrakcyjności wizualnej krajpobrazu Tab. 1. Criteria of evaluation of the visual attractiveness of landscape

\begin{tabular}{l|c}
\hline \multicolumn{1}{c}{ Kryterium } & Liczba punktów \\
\hline \multicolumn{2}{c}{ Liczba planów w krajobrazie } \\
\hline Trzy plany & 5 \\
\hline Dwa wyraźne z prześwitami trzeciego & 4 \\
\hline Dwa plany & 3 \\
\hline Jeden z prześwitami drugiego & 2 \\
\hline Jeden plan & 1 \\
\hline \multicolumn{1}{c}{ Liczba elementów krajobrazotwórczych } \\
\hline Krajobraz urozmaicony - powyżej 8 elementów & 5 \\
\hline Krajobraz średnio urozmaicony - 6-8 elementów & 3 \\
\hline Krajobraz mało urozmaicony - poniżej 6 elementów & 1 \\
\hline
\end{tabular}

Różnorodność elementów krajobrazotwórczych

Obiekty wodne

\begin{tabular}{l|l}
\hline Dominujące w krajobrazie & 2 \\
\hline Zauważalne - obecność bez dominacji & 1 \\
\hline Brak obiektów wodnych & 0 \\
\hline
\end{tabular}

Roślinność

Obecność zwartego lasu w krajobrazie oraz poje-

dyncze drzewa lub ich skupiska

Obecność tylko zwartego lasu, pojedynczych drzew lub ich skupisk

Roślinność krzewiasta

Brak roślinności drzewiastej i krzewiastej

Indywidualne obiekty przyrodnicze bądź antropogeniczne lub ich zespoły

Pozytywnie (podnoszące wartość, np. zabytki architektoniczne, stare cmentarze, estetyczna zabudowa, pomniki przyrody, malownicze drogi)

Obojętnie (ich istnienie nie wywiera żadnego wpływu na krajobraz, np. część linii trakcyjnych, dróg, domów, płotów)

Negatywnie (obniżające wartość, np. nieestetyczne zabudowania, wysypiska śmieci, wyraźne linie trakcyjne itp.)

Skrajnie negatywnie (silnie rażące pod względem estetycznym zespoły obiektów antropogenicznych dominujących $\mathrm{w}$ krajobrazie, $\mathrm{np}$. nieestetyczne fermy, zespoły baraków, wyjątkowo zaniedbane zabudowania)

\begin{tabular}{l|c}
\hline \multicolumn{2}{c}{ Harmonia krajobrazu } \\
\hline Krajobraz harmonijny & 5 \\
\hline Krajobraz o częściowo zaburzonej harmonii & 3 \\
\hline Krajobraz o mocno zaburzonej harmonii & 1 \\
\hline Krajobraz o całkowicie zaburzonej harmonii & 0 \\
\hline
\end{tabular}

\section{Struktura pionowa krajobrazu}

\begin{tabular}{l|c}
\hline Dobrze rozwinięta & 3 \\
\hline Średnio rozwinięta & 2 \\
\hline Słabo rozwinięta & 1 \\
\hline
\end{tabular}

Źródło: opracowanie własne na podstawie Skarżyńskiego (1992). Source: own compilation according to Skarżyński (1992). 


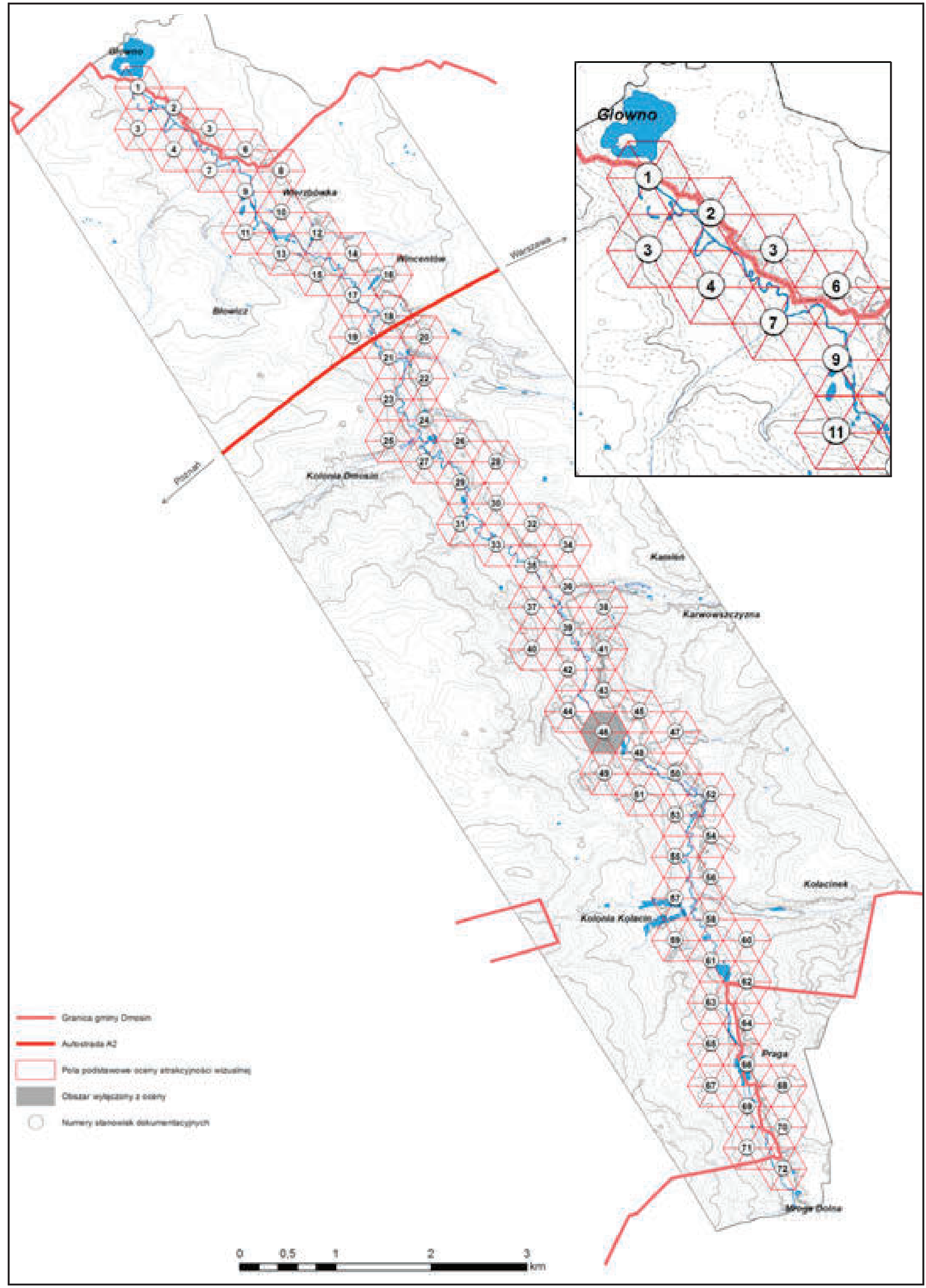

Rys. 3. Pola podstawowe oceny atrakcyjności wizualnej doliny Mrogi wg Mirowskiej (2015)

Fig. 3. Basic section of evaluation of the visual attractiveness of the Mroga valley according to Mirowska (2015) 


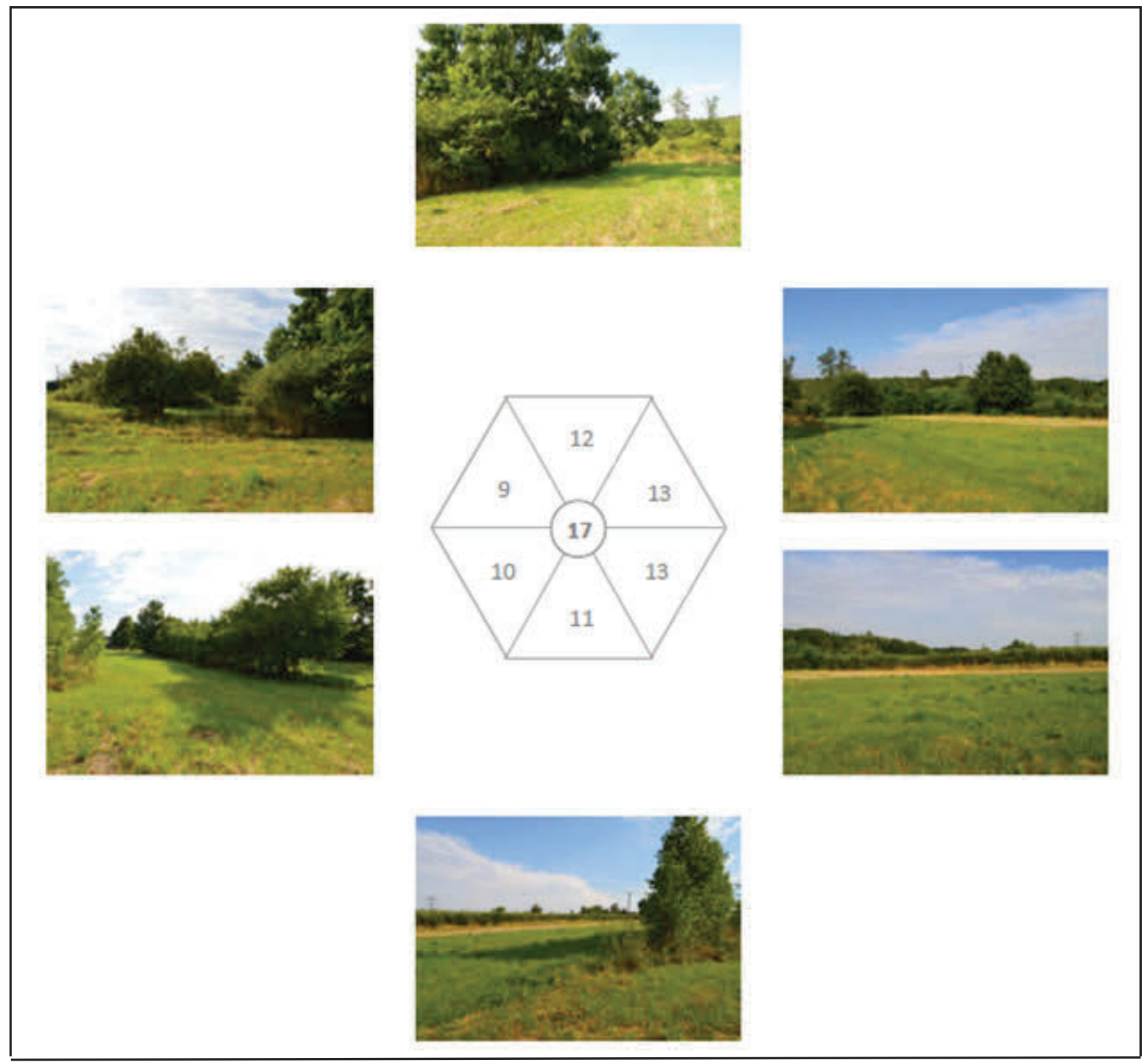

Rys. 4. Przykładowe stanowisko dokumentacyjne (fot. Mirowska 2014)

Fig. 4. Example of research position (Mirowska 2014)

lub poniżej to obszary nieatrakcyjne wizualnie. Zajęły one $4,7 \%$ obszaru badań.

Największą część stanowiły obszary o niewielkiej (od 7 do 10 punktów) i przeciętnej (od 11 do 13 punktów) atrakcyjności wizualnej. Zajmowały odpowiednio 37,8\% i 41,8\% powierzchni badanego terenu. Obszary o dużej atrakcyjności, czyli te, które uzyskały od 14 do 16 punktów zajęły $13,4 \%$ badanego terenu. Najmniejszy odsetek stanowiły obszary o największej atrakcyjności wizualnej. Stanowiły one zaledwie 2,6\% obszaru objętego badaniami.
Do stanowisk ocenionych najwyżej należą m.in. tereny znajdujące się przy zbiornikach wodnych, obejmujące łąki lub pola uprawne (fot. 1, 2). Cechują się one harmonijnością elementów krajobrazotwórczych.

Stanowiska, które uzyskały najniższą ocenę atrakcyjności wizualnej, obejmują przede wszystkim obszary znajdujące się w pobliżu autostrady $A 2$, przecinającej północną część badanego terenu, a także obszary, w granicach których znaczną część pokrycia terenu stanowią zabudowania (fot. 3, 4). 


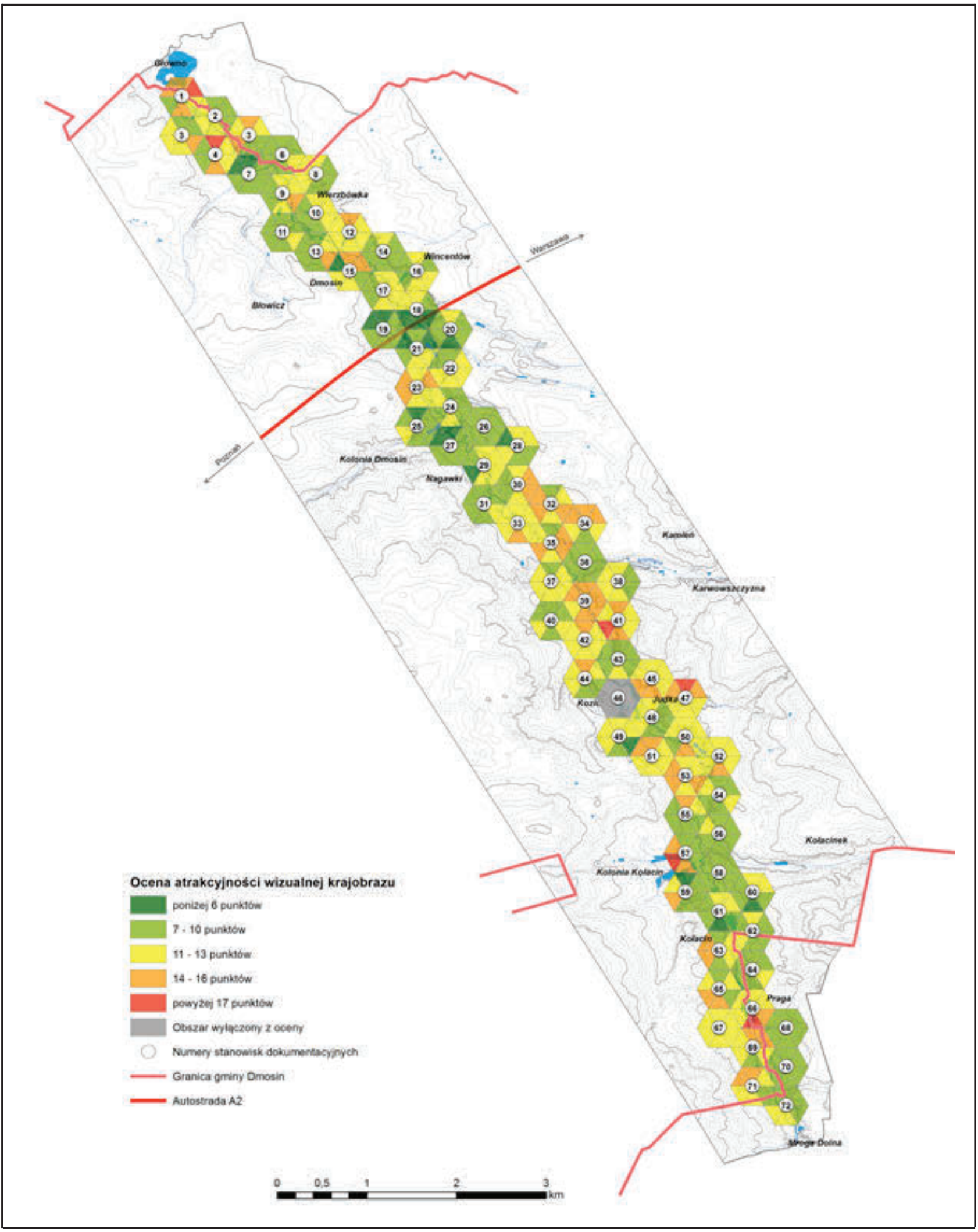

Rys. 5. Ocena atrakcyjności wizualnej doliny Mrogi i jej sąsiedztwa wg Mirowskiej (2015)

Fig. 5. Evaluation of the visual atractiveness of landscape of the Mroga valley and its surroundings according to Mirowska (2015) 


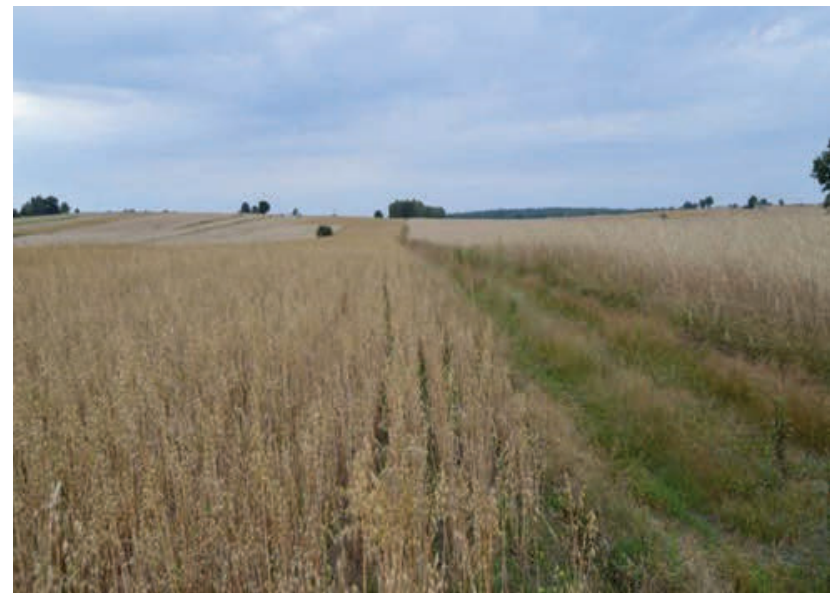

Fot. 1. Pole uprawne w okolicy wsi Judka (fot. Mirowska 2014)

Photo 1. Farmland near Judka village (Mirowska 2014)

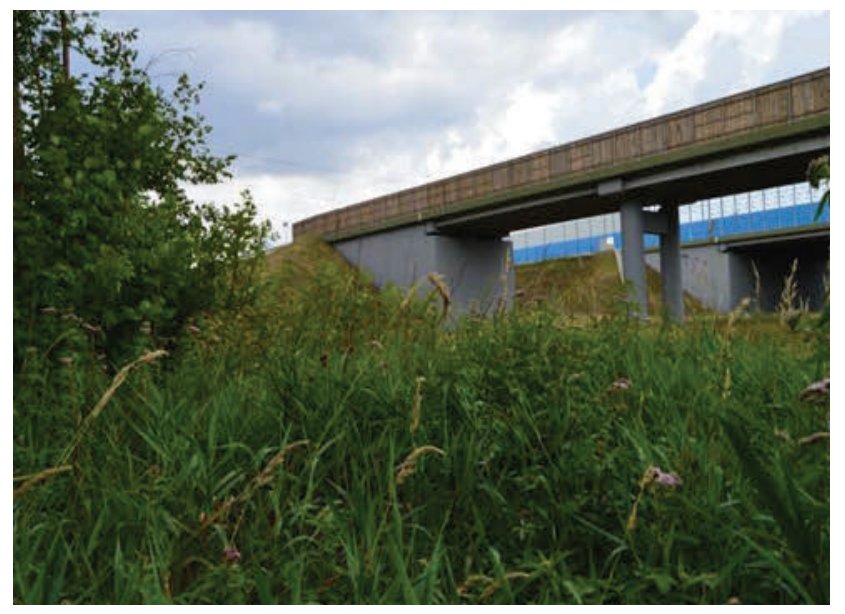

Fot. 3. Autostrada A2 (fot. Mirowska 2014)

Photo 3. A2 motorway (Mirowska 2014)

Najwyżej ocenionym stanowiskiem dokumentacyjnym było stanowisko numer 1 (rys. 6), które uzyskało łącznie 84 punkty. Dużą liczbę punktów otrzymało ono za bogactwo elementów krajobrazotwórczych, wpływających pozytywnie na harmonię całego widoku. Dominują tutaj obiekty wodne - zbiornik „Huta Józefów” w Głownie oraz fragment rzeki Mrogi. Obiekty antropogeniczne znajdujące się w obrębie tego stanowiska nie wpływają na kompozycję. Struktura pionowa krajobrazu jest dobrze rozwinięta, a harmonia krajobrazu zachowana bądź częściowo tylko zaburzona.

Natomiast najniżej ocenionym stanowiskiem było stanowisko numer 19 (rys. 7). Otrzymało ono 42 punkty. Co prawda, znaczna jest tu liczba elementów krajobrazotwórczych, jednak są one mało różnorodne i zaburzają harmonię całego widoku. Przeważają tu obiekty antropogeniczne - nieestetyczne zabudowania czy przebiegająca autostrada, które wpływają niekorzystnie na odczucia obserwatora. Brak naturalnych elementów budujących krajobraz takich, jak zbiorniki wodne, obniżają walory estetyczne stanowiska.

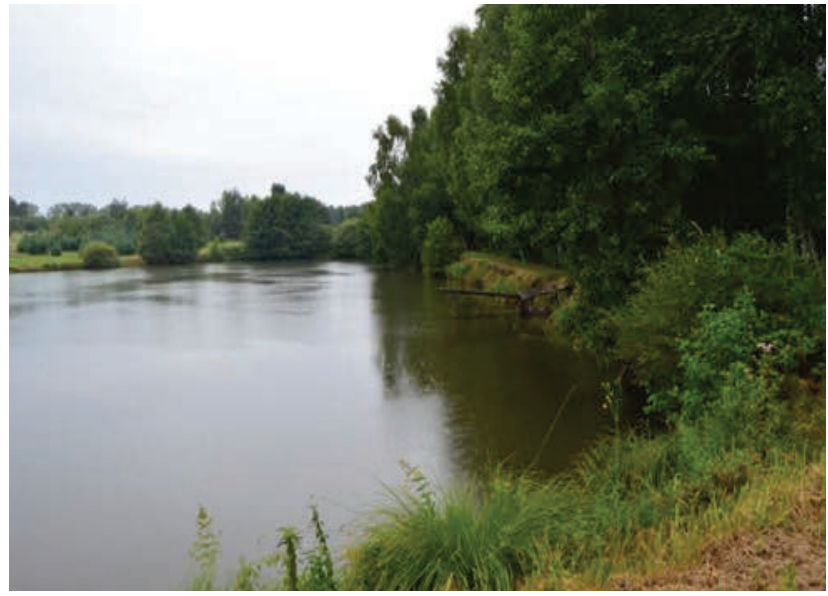

Fot. 2. Stawy hodowlane w okolicy wsi Kolonia Kołacin (fot. Mirowska 2014)

Photo 2. Breeding ponds near Kolonia Kołacin village

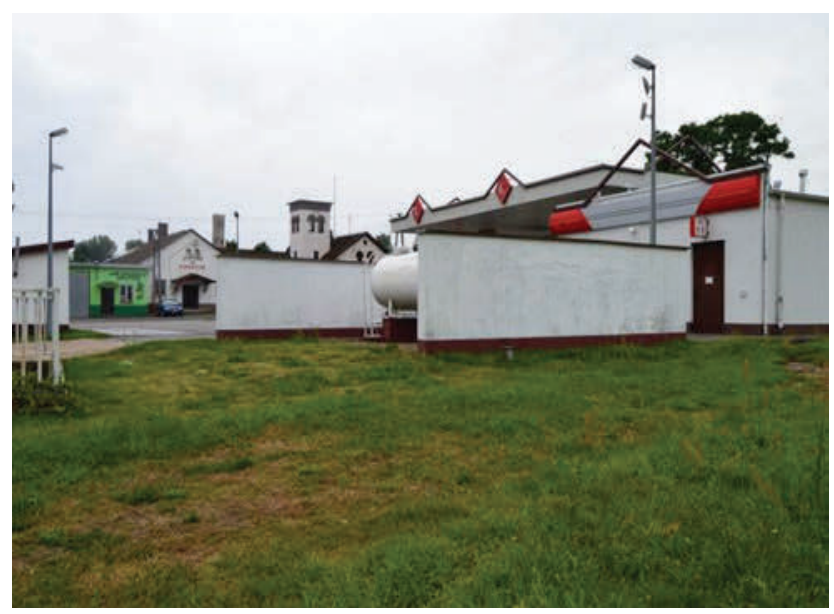

Fot. 4. Stacja paliw w Kołacinie (fot. Mirowska 2014)

Photo 4. Petrol station in Kołacin (Mirowska 2014)

\section{Wnioski}

Na podstawie wyników zmodyfikowanej metody fotograficznej Cymermana i Hopfera można stwierdzić, że na badanym terenie obszarami najbardziej atrakcyjnymi wizualnie są te z krajobrazami naturalnymi lub nieznacznie zmienionymi przez działalność człowieka. Można do nich zaliczyć łąki, pola uprawne, zbiorniki wodne. Najmniej atrakcyjnymi wizualnie są natomiast krajobrazy antropogeniczne, obszary zabudowane, zmienione w dużym stopniu przez działalność człowieka. Przede wszystkim są to: autostrada $A 2$, nieestetyczne zabudowania, a także obiekty takie, jak stacje benzynowe.

Przedstawiona metoda ma zarówno wady, jak i zalety. Jedną z wad jest to, że fotografia nie przedstawia całej powierzchni pola podstawowego podlegającego ocenie, a jedynie jego niewielki fragment. W szczególności uwaga ta odnosi się do obszarów występowania wysokiej roślinności, która w znacznym stopniu ogranicza zasięg pola widzenia. Koryto rzeki Mrogi, które mogłoby być najbardziej atrakcyjnym elementem krajobrazu badanego obszaru, jest wąskie, ulega postępującemu zarastaniu przez roślinność, co utrudnia dostęp do rzeki. Zdjęcia, wykonane w stanowiskach zlokalizowanych nawet w niedużej 


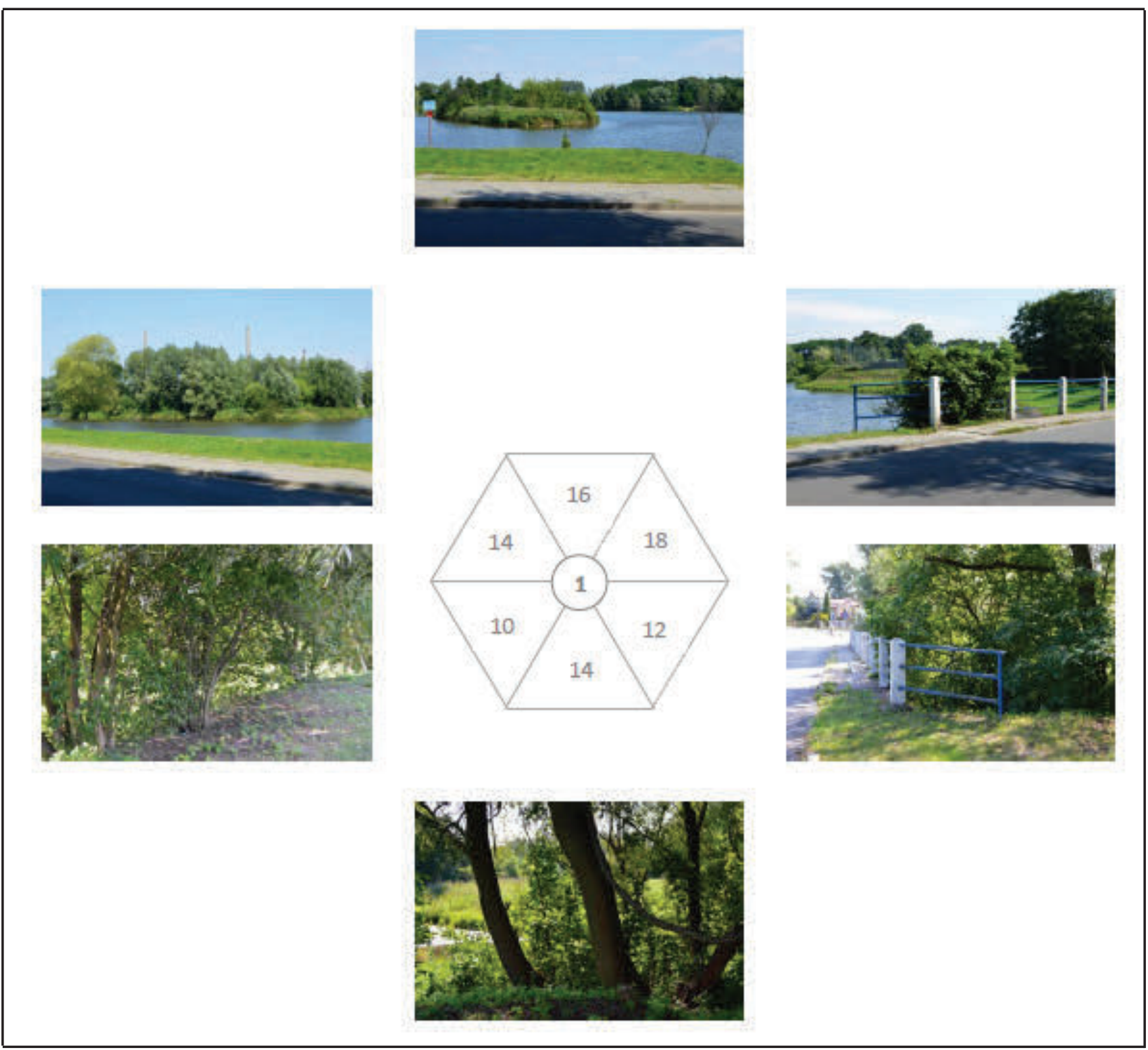

Rys. 6. Przykład stanowiska najbardziej atrakcyjnego wizualnie (fot. Mirowska 2014)

Fig. 6. Example of the most visually attractive research position (Mirowska 2014)

odległości od samej rzeki, nie oddają zatem w pełni jej atrakcyjności. W związku z tym rzeka ta nie budzi większego zainteresowania turystów.

Poza tym - mimo dobrania zobiektywizowanych kryteriów oceny - metoda cechuje się dużym stopniem subiektywizmu. Każdy posiada indywidualne preferencje, trudno wobec tego oceniać, zachowując jednocześnie pełną neutralność. Wynik oceny w znacznym stopniu jest więc uzależniony od osoby, która dokonuje oceny.

Kolejną wadą omawianej metody jest zastosowanie siatki pól podstawowych, które zostały wyznaczone w sposób losowy, przypadkowy. Nieznaczne przesunięcie siatki mogłoby wpłynąć na wynik oceny.

Zaletą metody jest możliwość uzyskania aktualnego obrazu badanego terenu poprzez równomiernie rozmieszczoną w przestrzeni sieć punktów dokumentacyjnych. Wykonane fotografie stanowią cenną ilustrację współczesnej fizjonomii badanego obszaru.
Warto zauważyć, że modyfikacja zaproponowana przez Hajnrych (2006) jest ulepszeniem metody Cymermana i Hopfera (1988). Zastosowanie pól podstawowych w kształcie sześciokątów zamiast kwadratów, a co za tym idzie - zastosowanie obiektywu o kącie widzenia $60^{\circ}$, pozwala na zaprezentowanie widoku bardziej zbliżonego do tego, który postrzega oko ludzkie.

$\mathrm{Na}$ koniec warto postawić pytanie, czy ocena atrakcyjności krajobrazu za pomocą przedstawionej wersji metody fotograficznej może być zbieżna z odczuciami turystów przebywających w dolinie Mrogi. Zazwyczaj w użytkowaniu turystycznym atrakcyjność krajobrazową poznajemy w trakcie przemieszczania się wzdłuż ścieżek, szlaków, duktów, dróg itp. Z tego powodu niezmiernie interesujące byłoby porównanie wyników otrzymanych ocen powierzchniowych z oceną atrakcyjności szlaków metodą Wejcherta. Powyższe porównanie może być inspiracją do dalszych badań nad poszukiwaniem optymalnych metod oceny atrakcyjności wizualnej krajobrazu. 


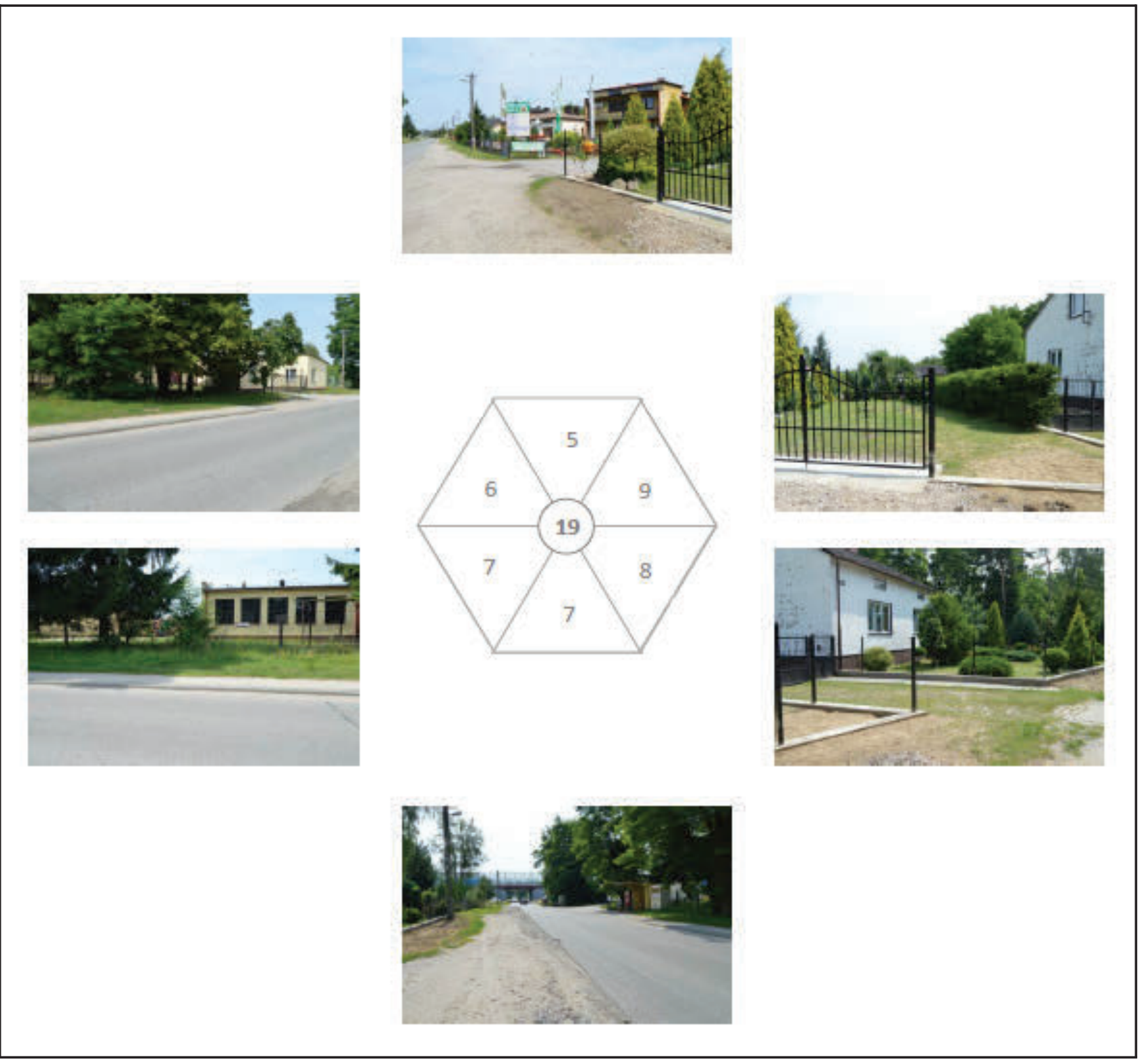

Rys. 7. Przykład najmniej atrakcyjnego wizualnie stanowiska dokumentacyjnego (fot. Mirowska 2014)

Fig. 7. Example of the least visually attractive research position (Mirowska 2014)

\section{Literatura}

Chmielewski, T.J., Sowińska-Świerkosz, B., Kułak, A., Chmielewski, Sz., 2014. Krajobrazy Roztocza: dziedzictwo natury i kultury. Lublin, 1-194.

Chmielewski, T.J., Kułak, A., Michalik-Śnieżek, M., Maślanko, W., 2015. Landscapes of the West Polesie. Regional identity and its transformation over last half century. Lublin-Urszulin, 1-132.

Cymerman, R., Hopfer, A., 1988. Wykorzystanie zdjęć fotograficznych do oceny krajobrazu obszarów wiejskich. Instytut Planowania i Urządzania Obszarów Wiejskich. Zeszyty Naukowe Akademii Rolniczo-Technicznej w Olsztynie, Olsztyn, 39-48.

Cymerman, R., Hopfer, A., Koreleski, K., Magiera-Braś, G., 1988. Zastosowanie metody krzywej wrażeń Wejcherta do oceny krajobrazów obszarów wiejskich. Zeszyty Naukowe Akademii Rolniczo-Technicznej w Olsztynie, Olsztyn, 29-38.

ECOVAST Landscape Identification. A guide to good practice (2006) (www.ecovast.org).

Hajnrych, M., 2006. Ocena środowiska geograficznego środkowej części dorzecza Grabi dla potrzeb turystyki i rekreacji. Maszynopis w Katedrze Geografii Fizycznej Uniwersytetu Łódzkiego, 1-147.
Kowalczyk, A., 1992. Metodologia i metodyka badań percepcji krajobrazu z punktu widzenia potrzeb turystyczno-wypoczynkowych, [w:] Metody oceny środowiska przyrodniczego. GEA2, Warszawa-Płock-Murzynowo, 25-33.

Królewski, P., 2014, Identyfikacja krajobrazów gminy Ręczno metodą ECOVAST. Maszynopis w Katedrze Geografii Fizycznej Uniwersytetu Łódzkiego, 1-183.

Królewski, P., Lidke, K., Majchrowska, A., 2015. Identyfikacja i charakterystyka krajobrazów w skali gminy - przykłady z województwa łódzkiego. DOI: 10.13140/RG.2.1.3844.1449.

Kuydowicz-Turkowska, K., 1975. Rzeczne procesy peryglacjalne na tle morfogenezy doliny Mrogi. Acta Geographica Lodziensia 36, 1-122.

Lidke, K., 2014. Identyfikacja krajobrazów gminy Inowłódz metodą ECOVAST. Maszynopis w Katedrze Geografii Fizycznej Uniwersytetu Łódzkiego, 1-189.

Mirowska, N., 2015. Atrakcyjność wizualna krajobrazu doliny Mrogi i jej sąsiedztwa w gminie Dmosin. Maszynopis w Katedrze Geografii Fizycznej Uniwersytetu Łódzkiego, 1-168.

Misiewicz-Śnieszko, Ł., 1982. Klimat, [w:] Gregorowicz, J. (red.), Województwo skierniewickie - monografia regionalna. UŁ, Łódź-Skierniewice. 
Pietrzak, M., Miedzińska, I., Styperek, J., 1999. Rzeczywista atrakcyjność wizualna krajobrazu szlaków turystycznych (na przykładzie szlaku im. Cyryla Ratajskiego w Wielkopolskim Parku Narodowym), [w:] Geoekologiczne podstawy badania i planowania krajobrazu rekreacyjnego. Problemy Ekologii Krajobrazu V, AWF, Poznań, 113-121.

Pizam, A., Neumann, Y., Reichel, A., 1978. Dimension of tourist satisfaction with destination area. Annals of Tourism Research 5(3), 314-322.

Prognoza oddziaływania na środowisko projektu miejscowego planu za gospodarowania przestrzennego gminy Dmosin, 2009, 6-12.

Richling, A., 1992. Podstawy metodyczne oceny wizualnej atrakcyjności krajobrazu, [w:] Metody ceny środowiska przyrodniczego. GEA 2, Warszawa-Płock-Murzynowo, 45-46.

Skarżyński, Z., 1992. Ocena walorów estetycznych krajobrazu okolic Piecek na Pojezierzu Mazurskim, [w:] Metody oceny środowiska przyrodniczego. GEA 2, Warszawa-Płock-Murzynowo, 47-54.
Śleszyński, P., 1999. Nowa metoda oceny atrakcyjności wizualnej krajobrazu, [w:] Pietrzak, M. (red.), Geoekologiczne podstawy badania i planowania krajobrazu rekreacyjnego. Problemy Ekologii Krajobrazu V, AWF, Poznań, 37-55.

Śleszyński, P., 1999. Percepcja atrakcyjności wizualnej okolic Pińczowa. Przegląd Geograficzny 23(3), Warszawa, 371-388.

Turkowska, K., 1988. Rozwój dolin rzecznych na Wyżynie Łódzkiej w późnym czwartorzędzie. Acta Geographica Lodziensia 57, 1-157.

Turkowska, K., 2006. Geomorfologia regionu łódzkiego. Wydawnictwo Uniwersytetu Łódzkiego, Łódź, 1-238.

Wojciechowski, K.H., 1986. Problemy percepcji i oceny estetycznej krajobrazu. Rozprawy habilitacyjne 28, UMCS, Lublin, 1-283. 